\title{
ANALYSIS OF THE NATURE OF SPIRITUAL PAIN IN TERMINAL PATIENTS AND THE RESIGNIFICATION PROCESS THROUGH THE RELAXATION, MENTAL IMAGES AND SPIRITUALITY (RIME) INTERVENTION
}

Ana Catarina Araújo Elias ${ }^{2}$ Joel Sales Giglio

Cibele Andrucioli de Mattos Pimenta

Elias ACA, Giglio JS, Pimenta CAM. Analysis of the nature of spiritual pain in terminal patients and the resignification process through the Relaxation, Mental Images and Spirituality (RIME) Intervention. Rev Latinoam Enfermagem 2008 novembro-dezembro; 16(6):959-965.

Objective: To understand Spiritual Pain and the new meaning it takes on using the RIME intervention. Subjects and methods: Eleven terminally ill patients $(n=11)$, treated at public hospitals, received care from six professionals trained for RIME application. The methods used were both qualitative, through phenomenology, and quantitative, based on the descriptive method, using the Wilcoxon Test. Results: In the qualitative approach, six categories and eleven subcategories were found. The prevailing categories were: fear of dying by denying the severity of the clinical condition ( $n=5)$; fear of dying by realizing the severity of the clinical condition $(n=5)$; fear of postmortem due to disintegration or feeling of non-existence, of being affectively forgotten $(n=5)$. In the quantitative analysis, a statistically significant difference $(p<0.0001)$ was noted. Conclusion: The results suggested that RIME promoted quality of life in the dying process, as well as more serenity and dignity in the face of death

DESCRIPTORS: spirituality; pain; hospice care; relaxation techniques; near-death experience; psychotherapy, brief; complementary therapies; humanization of assistance; death

\section{ANÁLISIS DE LA NATURALEZA DEL DOLOR ESPIRITUAL PRESENTADO POR PACIENTES TERMINALES Y EL PROCESO DE ELABORACIÓN DE UN NUEVO SIGNIFICADO A TRAVÉS DE LA INTERVENCIÓN DE RELAJAMIENTO, IMÁGENES MENTALES Y ESPIRITUALIDAD (RIME)}

Objetivo: Estudiar la naturaleza del Dolor Espiritual y el proceso de elaboración de un nuevo significado durante la aplicación de la Intervención RIME. Sujetos y métodos: Once pacientes terminales $(n=11)$, tratados en hospitales públicos, por seis profesionales entrenados para aplicar la RIME. Los métodos utilizados fueron el cualitativo con base en la fenomenología y el cuantitativo, a través del descriptivo, utilizándose la Prueba Wilcoxon. Resultados: En el abordaje cualitativo fueron encontradas seis categorías y once subcategorías. Las categorías que prevalecieron fueron: miedo de la muerte por negación de la gravedad del cuadro clínico $(n=5)$; miedo de la muerte por percepción de la gravedad del cuadro clínico $(n=5)$; miedo de la post-muerte por el sentimiento de desintegración, de dejar de existir, de ser afectivamente olvidado $(n=5)$. En el análisis cuantitativo se observó una diferencia estadísticamente significativa $(p<0,0001)$. Conclusión: Los resultados sugirieron que la RIME promovió la calidad de vida en el proceso de morir, así como propició más serenidad y dignidad delante de la muerte.

DESCRIPTORES: espiritualidad; dolor; cuidados paliativos; técnicas de relajación; experiencias de casi muerte; psicoterapia breve; terapias complementarias; humanización de la atención; muerte

\section{ANÁLISE DA NATUREZA DA DOR ESPIRITUAL APRESENTADA POR PACIENTES TERMINAIS E O PROCESSO DE SUA RE-SIGNIFICAÇÃO ATRAVÉS DA INTERVENÇÃO RELAXAMENTO, IMAGENS MENTAIS E ESPIRITUALIDADE (RIME)}

Objetivo: Estudar a natureza da Dor Espiritual e sua re-significação durante a aplicação da Intervenção RIME. Sujeitos e métodos: Onze pacientes terminais $(n=11)$, tratados em hospitais públicos, por seis profissionais treinados para aplicar a RIME. Os métodos utilizados foram o qualitativo com base na fenomenologia e o quantitativo, através do descritivo, utilizando-se o Teste Wilcoxon. Resultados: Na abordagem qualitativa foram encontradas seis categorias e onze subcategorias. As categorias prevalentes foram: medo da morte por negação da gravidade do quadro clínico $(n=5)$; medo da morte por percepção da gravidade do quadro clínico $(n=5)$; medo do pós-morte pelo sentimento de desintegração, de inexistir, de ser afetivamente esquecido $(n=5)$. Na análise quantitativa observou-se diferença estatisticamente significativa $(p<0,0001)$. Conclusão: Os resultados sugeriram que a RIME promoveu qualidade de vida no processo de morrer, assim como mais serenidade e dignidade perante a morte.

DESCRITORES: espiritualidade; dor; cuidados paliativos; técnicas de relaxamento; experiências de quase morte; psicoterapia breve; terapias complementares; humanização da assistência; morte

${ }^{1}$ The research was conducted at the Faculty of Medical Sciences, State University of Campinas, Brazil; ${ }^{2}$ Psychologist, Ph.D. in Medical Sciences, Faculty, Centro Universitário Nossa Senhora do Patrocínio, Brazil, e-mail: anacatarinaelias@uol.com.br, acatarina@fcm.unicamp.br; ${ }^{3}$ Psychiatrist, Associate Professor at Faculty of Medical Sciences, State University of Campinas, Brazil, e-mail: giglioj@uol.com.br; ${ }^{4}$ RN, Full Professor at University of São Paulo School of Nursing, Brazil, e-mail: parpca@usp.br. 


\section{INTRODUCTION}

$\boldsymbol{I}_{\mathrm{n}}$ order to give a new meaning to Symbolic Pain of Death for children, teenagers ${ }^{(1)}$ and adults $^{(2)}$, a new therapeutic intervention was developed, called Relaxation, Mental Images and Spirituality Therapy (RIME). It consists of integrating Mental Relaxation and Mental Images Viewing techniques with the elements that are part of the Spirituality issue ${ }^{(1-4)}$. The study ${ }^{(5)}$ continued with a Training Course on RIME for health professionals (Phase1), the analysis of the trained professionals' experiences in the application of RIME and the analysis of the patients' experiences in attributing a new meaning to their suffering through this intervention (Phase2). This issue will be discussed in the present article.

The theoretical references to develop RIME were related to the meaning and dimension of Spirituality ${ }^{(6-7)}$, the Near-Death Experiments(NDE) phenomena ${ }^{(8-9)}$, the spiritual needs of terminally ill patients ${ }^{(10)}$, the spiritual dreams and experiences related to the Terminal Stage $\mathrm{e}^{(2,4)}$ and the model developed to induce and apply Relaxation and Mental Images $^{(1-3)}$.

Spirituality does not refer to a specific religious faith, but to a transcendental relationship of the soul with divinity and the resulting change; that is, spirituality refers to an attitude, an inner action, greater awareness, an individual's contact with higher feelings and thoughts and the strengthening and maturing that this contact can mean for one's personality. Meditation is one of the possible routes to reach this transcendental relationship of the soul with divinity ${ }^{(6)}$.

Mediation between the conscious and unconscious, between the spiritual and physical world is performed using myths and symbolic images, because we cannot understand spiritual reality in its pure form using the three-dimensional elements in the material world. When the mind explores a symbol, it is guided by ideas that are beyond our reasoning ${ }^{(11)}$. Spirituality is related to experiencing the "Greater Love", which is an absolute and intangible feeling; it is a state of plenitude that manifests itself regardless of the circumstances. "Greater Love" is expressed as "Light", because it is not related to material aspects of one's existence, but to the universal virtues, which are demonstrated in the personality, through increased awareness about the meaning and reason of life ${ }^{(7)}$.
Near-Death Experiences (NDE) is the expression that classifies the group of people who were very close to death, came back to normal life and remember the spiritual experiences they had during NDE. The main elements described by these patients are: peace and absence of pain; floating out of the body sensation; ability to move at the speed of thought anywhere they want; ability to hear what physicians and relatives were saying with a perspective they would not have if they were in their bodies, lying down; view of a tunnel or gold and/or blue light path or view of beautiful bridges or decorated and pretty doors they would cross to reach another dimension, into the spiritual world; Spirits of Being who irradiated unconditional love, support, comfort, protection; entering beautiful places, such as flower gardens, woods and lakes and being involved by a very bright light; review their own lives not as a judgment, but in order to better understand what they really are, understanding the true meaning of life, which is learning unconditional love and acquiring knowledge, specially self knowledge; restructuring personality through contact with the Divine Light ${ }^{(8-9)}$.

In a qualitative study ${ }^{(10)}$ using semi-structured interviews, it was identified how terminally ill patients define spirituality and what their spiritual needs are. The conclusive key aspects were: spirituality refers to the quest for a meaning and purpose of life and makes us refer to a transcendental dimension; in order to improve the Quality of Life of agonizing patients, health professionals should take care of their spiritual as well as physical and psychological needs; the results indicate that the patients' spiritual needs are very broad, involving many aspects of their lives and much more than religion; providing spiritual care is a responsibility of health professionals to improve the Quality of Life of terminally ill patients.

The Spiritual Dreams and Experiences ${ }^{(2,4)}$ were also studied, collected from terminally ill patients, their relatives and the psychologist responsible for direct patient care. Even though most of the dreams are compensatory, in some cases, they have a different nature. These non-compensatory dreams suggest the following classification: anticipatory, traumatic, extrasensorial and prophetic.

Dreams of near-death people indicate that the unconscious prepares conscience not for an ultimate end, but for a type of continuation of the vital process which everyday conscience cannot even imagine ${ }^{(11)}$. 
Data collected ${ }^{(2,4)}$ have shown that, when patients beyond any hope for cure are near death, they can have non-compensatory, anticipatory, precognitive or telepathic dreams, which reflect extrasensorial perceptions. During the study ${ }^{(2,4)}$, these noncompensatory dreams were observed in the patients, their relatives and the psychologist. These dreams suggested the existence of postmortem spiritual life and this was a complementary contribution for the patients' new meaning of Spiritual Pain, and to prepare relatives for mourning.

The association between Mental Relaxation and Mental Image Viewing provided greater contact with inner subjective reality and promoted changes in attitudes and ideas related to current suffering experiences $^{(1-3)}$.

Based on the results ${ }^{(2)}$, the survey ${ }^{(5,12-13)}$ continued with the development of a training program on RIME Intervention for health professionals; both these professionals' experience during the application of this intervention and the nature of patients' Spiritual Pain and the process of giving it a new meaning were studied.

\section{OBJECTIVE}

In this article, we will discuss the nature of Spiritual Pain in terminally ill patients and the experience of giving this Pain a new meaning, expressed by the patients during the application of RIME Intervention.

\section{SUBJECTS AND METHODS}

Eleven patients in terminal cancer conditions went through the procedure in public hospitals in the cities of Campinas, São Paulo and Piracicaba, Brazil. The procedures were performed by six health professionals (a nurse, a physician, three psychologists and a volunteer alternative therapist), who took the proposed Training Program ${ }^{(5,12-13)}$. These professionals were invited to join the group and all of them were experienced or experts in the field of palliative care.

Participants were selected by the trained professionals to take part in the RIME Intervention, based on the observation of patients going through a lot of pain in the dying process; these patients had been diagnosed as with no chance of cure by the medical team in charge, except for one female patient, who had the RIME Intervention because the nurse noticed that, even though she might be cured, she was progressing to death with a lot of pain, and this actually happened the morning after the intervention procedure.

The methods used were both qualitative and quantitative.

The qualitative theoretical basis was established in phenomenology, which is usually defined as a study of what was experienced in life and its meanings. There are several types of phenomenological research and, in this study, empirical phenomenology. The instruments used to collect qualitative data were twenty-one semistructured interviews and eleven structured questionnaires; Spiritual Pain and the process of giving a new meaning to this Pain were identified qualitatively by the professionals who performed the procedure, transcribed into the structured questionnaire and analyzed together with the researcher during the supervision interviews. The qualitative results were analyzed through Thematic Content Analysis.

Quantitative analysis was based on the descriptive method, which attempts to describe the features of a given phenomenon or population in order to establish relationships between variables and facts; the instrument used was a scale, which is planned to attribute a numerical score to the subjects, placing them on a continuum in terms of the measured attributes, such as a balance used to measure people's weight.

The Visual Analogue Scale (VAS) with colored facial expressions was chosen, as the intention was to measure subjective issues related to Spiritual Pain, and the numerical pattern could be too "cold" to assess these propositions. Faces with different colors and expressions can permit better identification for the patient to express the intensity of fear, ideas, guilt, feelings and emotions. It was also noticed that, perhaps, because the faces are presented in a cheerful way, they are more suitable for terminal patients who generally tend to be emotionally fragile because of their clinical conditions. The scale used comprises six colored faces whose expressions range from absence of pain to unbearable pain. The blue face (10) expresses no pain at all; the blue-greenish face (8) expresses light pain; the green face (6) expresses moderate pain; the yellow face (4) expresses annoying 
pain; the orange face (2) expresses intense pain; the red face (0) expresses unbearable pain.

The VAS was shown to the patients at the beginning and at the end of each session. For the sake of a better understanding, the dataabout "WellBeing" manifested by the patients, before and after the RIME sessions, were calculated through medians and averages per patient, and the number of sessions in which "Well-Being" improved was also calculated. Rates at the end and the beginning of each session were compared, based on the medians, using the Wilcoxon Test.

\section{ETHICAL ASPECTS}

The present article refers to a doctoral thesis, which involved the development of a training program for health professionals about the Therapeutic Intervention RIME. This intervention was put in practice in the senior author's master's thesis, whose project was approved by the Ethics and Research Committee at the Campinas State University College of Medical Sciences, registered as 194/99, homologated in the 1st Meeting of the CEP/FCM in 2000. The project of this doctoral thesis was approved without restrictions by the Ethics and Research Committee at the Campinas State University College of Medical Sciences, registered as 023/2002 and homologated in the VII Ordinary Meeting of CEP/FCM, in August 2002.

\section{RESULTS}

Concerning the nature of Spiritual Pain, analyzed in the qualitative approach, six categories and eleven subcategories were found, described below and illustrated by some examples:

Fear of death expressed by denial of gravity of clinical stage. $(n=5)$

Difficulty to accept diagnoses and clinical care

Attachment to concrete and material world

Patient: P.M. (Male, 76, Prostate cancer with metastasis and medullar compression, Catholic, Metallurgic Technician). Spiritual Pain: Defensive attitude in accepting terminal condition, represented by belief that he would walk again and denial that the picture was irreversible.

New meaning of Spiritual Pain: After the first interventions, the patient reported he was feeling better after the RIME application. In subsequent sessions, the patient said he did not find relief, although he relaxed during the session (REM state noted), and slept quietly after RIME and also at night. Due to his dramatic attitude during the sessions, the patient was expected to die with a lot of "crying and grinding", but that did not happen, he died quietly and wrote in verses, one day before dying, that he had accepted death.

Fear of death expressed by perception of gravity of clinical stage. $(n=5)$

Concern with physical suffering

Non-verbal expressions of tension, fear and terror

Aggravation of clinical symptoms

Patient: M.L.C.I. (Female, 57, Breast Cancer, Catholic, Housewife).

Spiritual Pain: Frightened face, which made her family worry.

New meaning of Spiritual Pain: The patient suffered from severe respiratory problems and the family asked the doctors if there was anything to relieve this distress. The medical team said they were doing all they could about it. That same afternoon, RIME was applied and the patient's daughter-in-law said there was something else that could be done, i.e. this intervention, because the patient showed improvement from the dyspnea and her face softened, looking calm.

Fear of after-death based on negative experience in spiritual dreams. $(n=2)$

Viewing terrifying or very scary images

Patient: M.S.S. (Female, 27, Cervix cancer with vertebra and bladder invasion, Protestant, Cleaning Aid).

Spiritual Pain: Expressed by visions of negative and frightening images she had before the RIME Intervention. She saw snakes on the wall and said people wanted to kill her, among other bad things. 
New Meaning of Spiritual Pain: After the beginning of the RIME application, the patient started seeing a very enlightened person next to her at night, the presence of a very strong Light and children; according to her, the feeling was very good. Before the psychologist taking care of her arrived to start the session, she would see children, and she said there was always a lady next to the psychologist.

Fear of after-death expressed as negative affective feelings of disintegration, non-existence or being forgotten $(n=5)$

State of heightened alertness

Separation anxiety

Doubts about Divine Love

Patient: M.A.S. (Female, 63, Meta Hepatic Pathology (Hidden Primary Tumor), Protestant, Service Aid at the Secretariat of Finance).

Spiritual Pain: Afraid to close her eyes and sleep, as an extension or expansion of a lack of affection she seemed to live in.

New meaning of Spiritual Pain: During the first session, M.A.S. kept making different faces and sounds as if she was groaning or humming to herself. At the end of the session, she felt delighted with what she had experienced in her visualization; she clearly showed that she had understood what spiritual experience was like and that there would be life after death.

Negative ideas and concepts about the meaning of life expressed by absence of feelings or feelings of existential void. $(n=4)$

Previous negative experiences of affective or productive nature

Patient: M.S.S. (Female, 27, Cervix cancer with vertebra and bladder invasion, Protestant, Cleaning Aid).

Spiritual Pain: Pessimism due to her experiences of abandonment and loneliness.

New meaning of Spiritual Pain: After RIME sessions, the patient always said she was calmer. Her face would soften up and sometimes she referred to a relief to her physical pain. She died in her mother's arms who, due to RIME, lost her fear of being at the hospital.

Negative ideas and concepts of spirituality caused by experience of affective abandonment projected to spirituality. $(n=2)$

Difficulty of transcendence and trust in spiritual beings

Patient: Patient E.O.G. (Female, 74, Carcinoma, Catholic, Housewife)

Spiritual Pain: Voracious appetite despite inability to eat.

New meaning of Spiritual Pain: She understood it was impossible to eat physically speaking, after a symbolical connection with spiritual nourishment through visualization of the Light tunnel.

Medians and averages per patient and the number of sessions with improved "well-being" were calculated. A statistically significant difference $(p<0.0001)$ was noticed.

\section{DISCUSSION}

In a study with twelve blood cancer survivors, Spiritual Pain was studied using semi-structured interviews. It was seen as a threat to the patient's life, in view of the rupture with normal daily life, expected relationships, satisfaction with life and the loss of identity, due to an invasive and aggressive treatment. When disconnection is acute and painful (a subjective phenomenon varying according to individuals), this is experienced as "Spiritual Pain", creating a void that challenges individuals' ability to maintain a meaning for their existence ${ }^{(14)}$. It was noticed in the study with patients surviving severe illness, as well as in the present survey with terminally ill patients, that the acceptance process of the new conditions created by the illness causes existential pain and requires attention and important care by health professionals.

Fear of death, represented by denial and by the perceived severity of the clinical condition, which has shown to be a prevailing aspect of Spiritual Pain, is expressed in the direct relationship between patients and the health team, in the way patients handle their own symptoms and react to care they receive. We find it very important to understand the representations of Spiritual Pain since, many times, 
professionals relate the attitude of patients expressing this Pain to the personal level, which leads to unnecessary professional stress, as well as insufficient attention to the patients' needs.

The fear of post-mortem, related to dreams and negative spiritual experiences, and to the feeling of disintegration or non-existence, of being affectively forgotten, requires special attention from health professionals, in view of the new diagnosis category called "religious or spiritual problem", which was included in the fourth edition of the Mental Disorder Diagnostic and Statistic Manual (DSM-IV); the addition of this new category offers the opportunity of a new relationship between psychiatrists and the fields of religion and spirituality, benefitting both mental health professionals and help-seeking patients ${ }^{(15)}$.

In both studies ${ }^{(2,5)}$, when the patients' negative spiritual experiences were addressed through the RIME Intervention as actual experiences, and not as hallucinations, there was a significant improvement in the pattern of these experiences, relieving pain. As to NDE, it was noticed that what makes this kind of experience negative is the individual's lack of mental connection with transcendental aspects of love and opening to spirituality, which are exactly the aspects motivated by the RIME application.

As to negative ideas and conceptions related to the meaning of life, due to the lack of this meaning and feelings of existential void, and regarding spirituality through affective abandonment experiences projected in this spirituality, it was observed that the RIME procedures motivated patients to recover positive aspects of their life history and finish uncompleted tasks, either at the intrapsychic level or at the interpersonal relationship level.

In qualitative analysis, it was observed that RIME procedures favored the new meaning of Spiritual Pain in a customized way, according to each patient's specific expression.

In quantitative analysis, a statistically significant difference $(p<0.0001)$ was noticed, that is, at the end of RIME sessions, patients reported a higher level of well being than at the beginning of the session.

It was also observed that a new meaning is attributed to Spiritual Pain according to a procedure and, even though there is no rule regarding intervals between sessions, some patients referred worse wellbeing in this interval. Therefore, it is recommended that intervals be short, within the patients' possibilities.
One of the psychologists, for example, had two RIME sessions on the same day about patient M.S.S., with proven benefit.

Regarding age, religion and profession, for patients of both genders with some type of cancer, the socio-demographic data indicated that the RIME Intervention produced satisfactory results, minimizing pain in the dying process of a diversified population.

Patients' ages varied from twenty-seven to seventy-six years old, which indicated the possibility of using RIME for adults of all ages, as well as elderly people. Another study found satisfactory outcomes with children and adolescents ${ }^{(1)}$.

The sample patients' professions ranged from very low educational background to a higher education degree, which suggested the possibility of applying RIME to people of any educational background.

As to religion, the participating patients had different religious beliefs, including catholic, spiritualist, and several evangelical denominations, which indicated the possibility of addressing the spirituality issue through RIME, regardless of the patient's religious faith.

Health professionals can no longer ignore spiritual practices. A qualitative study ${ }^{(16)}$ assessed how spirituality permeates the process of caring for oneself and for others in the intensive care scenario from nursing professionals' point of view. One of the topics that emerged during this process was spirituality in self-care, which is evidenced in the daily practices that take place through prayers, close contact with nature, as well as in the sense of connection with a Higher Power that provides peace, well-being, and greater strength to the life and work of Intensive Care Unit caregivers. Self-knowledge emerged as an essential practice in self-care, in order to deliver better care to others. Research(17) aimed to identify the opinion of nursing teachers about spirituality and spiritual care within their education program, as well as its presence in courses and their suggestions for the inclusion of spiritual aspects. Twenty-four teachers were interviewed in November 1994; 95.8\% of them thought human beings were spiritual beings, mentioning in what ways this dimension alters and influences their daily life; $66.6 \%$ of the teachers thought about the importance of including spiritual care in their educational program. In the light of the range of answers, the authors emphasize the need to reflect on this subject. 


\section{CONCLUSIONS}

The qualitative and quantitative analysis of the new meaning attributed to Spiritual Pain by terminally ill patients suggested that the RIME intervention promoted quality of life in the dying process, as well as more serenity and dignity before death.

The most relevant aspects of Spiritual Pain, fear of death and post-mortem were observed.
As to the limitations in this research, it was observed that the study design did not permit the use of a control group to compare RIME results with results from other interventions. The second limitation referred to the sample size. Although the results were significant and collected through a rigid academic method, they cannot be generalized. Further studies will be developed in order to work on these limitations.

\section{REFERENCES}

1. Elias ACA. Re-significação da dor simbólica da morte: relaxamento mental, imagens mentais e espiritualidade. Psicologia: Ciência e Profissão 2003; 23(1):92-7.

2. Elias ACA. Relaxamento mental, imagens mentais e espiritualidade na

re-significação da dor simbólica da morte da pacientes terminais. [dissertação]. Campinas (SP): Faculdade de Ciências Médicas/UNICAMP; 2001.

3. Elias ACA, Giglio JS. Intervenção psicoterapêutica na área de cuidados paliativos para re-significar a dor simbólica da morte de pacientes terminais através de relaxamento mental, imagens e espiritualidade. Rev Psiquiatr Clín. 2002; 29(3): 116-29.

4. Elias ACA, Giglio JS. Sonhos e vivências de natureza espiritual relacionados à fase terminal. mudanças. Psicol Saúde 2002 janeiro-junho; 10(1):72-92.

5. Elias ACA. Programa de Treinamento sobre a Intervenção Terapêutica Relaxamento, Imagens Mentais e Espiritualidade (RIME) para re-significar a dor espiritual de pacientes terminais. [tese]. Campinas (SP): Faculdade de Ciências Médicas/UNICAMP; 2005.

6. Jung CG. Obras completas. Petrópolis (RJ): Editora Vozes; 1986.

7. Charuri C. Como vai a sua mente? $3^{a}$ ed. São Paulo (SP): PC Editorial; 2001.

8. Greyson B. Dissociation in people who have near-death experiences: out of their bodies or out of their minds? Lancet 2000 February 5; 355(9202):460-3.
9. Lommel P, Wees R, Meyers V, Elfferich I. Near-death experience in survivors of cardiac arrest: a prospective study in the Netherlands. Lancet 2001 December 15; 358(9298):2039-45.

10. Hermann CP. Spiritual needs of dying patients: a qualitative study. Oncol Nurs Forum 2001 january-february; 28(1):67-72.

11. Jung CG. Memórias, sonhos, reflexões. $21^{\mathrm{a}}$ ed. Rio de Janeiro (RJ): Nova Fronteira; 2001.

12. Araújo Elias AC, Giglio JS, Mattos Pimenta CA, El-Dash LG. Therapeutical intervention, relaxation, mental images, and spirituality (RIME) for spiritual pain in terminal patients. A training program. Scientific World Journal 2006; 6:2158-69. 13. Elias ACA, Giglio JS, Pimenta CAM, El-Dash LG. Programa de treinamento sobre a intervenção terapêutica relaxamento, imagens mentais e espiritualidade (RIME) para re-significar a dor espiritual de pacientes terminais. Rev Psiquiatr Clín (São Paulo) 2007; 34(1):60-72.

14. Mc Grath P. Creating a language for 'spiritual pain' through research: a beginning. Support Care Cancer 2002; 10(8):637-46.

15. Turner RP, Lukoff D, Barnhouse RT, Lu FG. Religious or spiritual problem. A culturally sensitive diagnostic category in the DSM-IV. J Nerv Ment Dis 1995 July; 183(7):435-44. 16. Dezorzi LW, Crossetti MGO. Spirituality in self-care for intensive care nursing professionals. Rev. Latino-Am. Enfermagem 2008 march-april; 16(2):212-7.

17. Benko MA, Silva MJP. Thinking about spirituality within nursing undergraduate program. Rev Latino-Am. Enfermagem 1996 january; 4(1):71-85. 